\title{
Unravelling the Pathogenesis and Molecular Interactions of Liberibacter Phytopathogens with Their Psyllid Vectors
}

\author{
Poulami Sarkar ${ }^{(D)}$ and Murad Ghanim *(D) \\ Department of Entomology, Volcani Center, Rishon LeZion 7505101, Israel; poulamisarkarbt@gmail.com \\ * Correspondence: ghanim@volcani.agri.gov.il
}

Received: 30 June 2020; Accepted: 1 August 2020; Published: 4 August 2020

\begin{abstract}
Insect-borne bacterial pathogens pose a global economic threat to many agricultural crops Candidatus liberibacter species, vectored by psyllids (Hemiptera: psylloidea), are an example of devastating pathogens related to important known diseases such as Huanglongbing or the citrus greening disease, Zebra chip disease, and carrot yellowing, along with vegetative disorders in umbellifers. Studies on liberibacter-plant interactions have gained more focus in disease control over the last few decades. However, successful and sustainable disease management depends on the early disruption of insect-pathogen interactions, thereby blocking transmission. Recent knowledge on the liberibacter genomes and various omics approaches have helped us understand this host-pathogen relationship, despite the complexity associated with the inability to culture these bacteria. Here, we discuss the cellular and molecular processes involved in the response of insect-host immunity, and the liberibacter-associated pathogenesis mechanisms that involve virulence traits and effectors released to manipulate the insect-host defense mechanism for successful transmission. Understanding such mechanisms is an important milestone for developing sustainable means for preventing liberibacter transmission by psyllids.
\end{abstract}

Keywords: liberibacter; psyllids; vector-borne bacteria; pathogenicity; insect defense; phloem-limited bacteria

\section{Introduction}

Candidatus liberibacter species and the diseases they cause have gained recent importance due to their rapid proliferation, leading to global economic losses [1-3]. Liberibacter spp. are phloem-limited Gram-negative alphaproteobacteria transmitted by psyllids (Hemiptera: Psylloidea), and are only able to multiply either in the plant host or in the insect vector. They primarily depend on one psyllid species for transmission, and are confined to the plant phloem on which their insect vectors feed [4-6]. Presently, liberibacter-caused diseases are associated with a limited number of crop families, including Rutaceae, Solanaceae, Umbelliferae, and Rosaceae. The number of plant species infected by Liberibacters is restricted by the host range of their psyllid vectors. Huanglongbing or HLB (citrus greening disease), caused by Ca. L. asiaticus (CLas) in Asia and the Americas, by Ca. L. africanus in Africa, and by Ca. L. americanus in Brazil, has heavily impacted citrus production and the related industries and economies [2,7-12]. Other diseases that are gaining much economic importance are Zebra chip disease in potatoes, transmitted by Bactericera cockerelli (Šulc; Hemiptera: Triozidae) in the Americas and New Zealand, as well as several vegetative disorders in carrots and celery, transmitted by Trioza apicalis (Förster; Hemiptera: Triozidae) in Northern Europe and by B. trigonica in the Mediterranean and the Middle East, caused by different haplotypes of Ca. L. solanacearum (CLso) [2,5,13-16]. The first natural transmission of liberibacter in citrus was identified by the citrus psylla Trioza erytreae (Del Guercio; 
Hemiptera: Triozidae) in Africa [17], and by the Asian citrus psyllid Diaphorina citri Kuwayama (Hemiptera: Liviidae) in Asia. Diaphorina citri is the principal insect vector for CLas in Asia, Brazil, and the United States [18-21]. All of the known liberibacter species vectored by different psyllid species and their diseases are summarized in Table 1.

While the interactions of liberibacter species with their plant hosts are being extensively studied, molecular interactions with psyllid vectors are not drawing much of the research attention. The fastidious nature of liberibacter and the inability to culture the bacteria of this genus restrains a better understanding of pathogenesis within the insect and plant hosts, although one of these species, L. crescens, has been cultured [22]. Recent detection methods and sequencing techniques have made it easier to address questions related to understanding the molecular dynamics of the different bacteria within their insect and plant hosts. Over the last decade, while acquisition and persistence of liberibacter in insect vectors have been immensely studied [23-27], molecular mechanisms of the pathogenicity, transmission, and persistence within insects are pending and require more extensive research. The fact that the complex of diseases caused by liberibacter species are causing great economic losses around the world creates exigency for developing rapid and sustainable control methods, either by developing resistance on the plant front or interfering with the transmission of the pathogen by the vector. In this review, we focus on understanding the pathogenesis of liberibacter species within their insect vector, which may lead to the identification of targets for disrupting the transmission.

\section{Life Cycle in Psyllid Host}

Liberibacter follows a persistent and circulative pathway inside the psyllid host. After ingestion by the psyllid through its stylet during feeding from the phloem of an infected plant, the bacteria moves through the food canal in the stylet and reaches the lumen of the gut. The bacteria then translocates across the gut cells, breaching cellular barriers, and enters the hemolymph, where it circulates with the blood stream to reach various organs, including the salivary glands from which it will be injected into the host plant $[1,18,28,29]$. This pathway in the insect involves hijacking the host immunity and manipulating the host cell factors to enable bacteria propagation inside the host cells, and to further enable movement from one cell to another. The processes that enable the persistence of the bacterial cells inside the insect cells involve focal adhesion; cellular invasion and vesicular trafficking; paracytophagy; and, most importantly, escaping host defenses for persistence. Once acquired, especially by nymphs, liberibacter can be harbored by adults throughout their life span $[18,21,30]$. The distribution of liberibacters is ubiquitous throughout the hemolymph of the infected psyllid, with the midguts and salivary glands containing a high bacterial load [23]. A vast majority of Gram-negative bacterial pathogens are known to be vertically transmitted from parents to offspring. However, liberibacters have a very low rate of vertical (transovarial) transmission in the psyllids. CLas is reported to be vertically transmitted by D. citri at a rate of 3.6-18\% [25,31]. Rate of sexual transmission is also low $(<4 \%)$ [32]. The low rate of vertical (transovarial) transmission also implies that liberibacter primarily depends on the psyllid host for multiplication and efficient transmission $[29,33]$. The developmental stage of the insect vectors also impacts liberibacter transmission. The nymphs have been reported to acquire more liberibacters than adults due to their less developed immune systems $[25,33]$ and because of their prolonged phloem ingestion compared with adults [34]. Consistently, CLas transmission by D. citri is higher when acquired by nymphs compared with adults $[25,28,33,35,36]$. A recent transcriptomic study in Bactericera trigonica Hodkinson (Hemiptera: Triozidae) infected with CLso showed higher metabolic and immune changes in the adults than in the nymphs (1). The latent period, which is the time that passes from acquisition until the insect becomes capable of transmitting the pathogen, during which the bacteria circulates in the insect body, varies between each psyllid species and developmental stages (Table 1). A two week latent period has been measured for CLso transmission by B. cockerelli, whereas at least 7 to 10 days are needed for efficient CLas transmission by D. citri $[28,37,38]$. 
Table 1. Liberibacter-associated diseases, the infected host plants, insect vectors, and other biological and molecular parameters.

\begin{tabular}{|c|c|c|c|c|c|}
\hline Liberibacter & Insect Host & Plant Host & Latent Period & Genome Size & Ref \\
\hline Liberibacter crescens (Lcr) & Unknown & Hybrid mountain papaya (Carica stipulata $\times$ C. pubescens) & - & $1.4 \mathrm{Mb}$ & [39] \\
\hline $\begin{array}{l}\text { Candidatus Liberibacter } \\
\text { asiaticus (CLas) }\end{array}$ & $\begin{array}{l}\text { Diaphorina citri (Asian } \\
\quad \text { citrus psyllid) }\end{array}$ & Citrus and citrus relatives & 1 week & $1.23 \mathrm{Mb}$ & {$[28,40]$} \\
\hline Ca. L. africanus (CLaf) & $\begin{array}{l}\text { Trioza erytreae (African } \\
\text { citrus psyllid) }\end{array}$ & $\begin{array}{l}\text { Citrus, Flaky cherry-orange (Teclea gerrardii), White ironwood } \\
\text { (Vepris), Small forest knobwood (Zanthoxylum), Horsewood } \\
\text { (Clausena), and Cape chestnut (Calodendrum capense) }\end{array}$ & Not reported & $1.19 \mathrm{Mb}$ & [41] \\
\hline Ca. L. americanus (Lam) & D. citri & Citrus and citrus relatives & Not reported & $1.19 \mathrm{Mb}$ & [42] \\
\hline $\begin{array}{l}\text { Ca. L. solanacearum } \\
\text { (CLso) Haplotype A }\end{array}$ & Bactericera cockerelli & Solanaceous crops & 2 weeks & $1.26 \mathrm{Mb}$ & {$[38,43]$} \\
\hline CLso haplotype B & B. cockerelli & Solanaceous crops & 2-3 weeks & - & [38] \\
\hline CLso haplotype C & Trioza apicalis & Carrot & Not reported & $1.24 \mathrm{Mb}$ & [44] \\
\hline CLso haplotype D & Bactericera trigonica & Carrot & Not reported & $1.3 \mathrm{Mb}$ & [45] \\
\hline CLso haplotype E & B. trigonica & Celery and carrots & Not reported & Not reported & - \\
\hline Ca. L. europaeus (Leu) & Cacopsylla pyri & $\begin{array}{c}\text { Apple (Malus domestica), hawthorn (Crataegus monogyna), } \\
\text { blackthorn (Prunus spinosa), and pear (Pyrus) }\end{array}$ & Not reported & Not reported & - \\
\hline Ca. L. europaeus (Leu) & Arytainilla spartiophila & Scotch broom (Cytisus scoparius) & Not reported & $1.33 \mathrm{Mb}$ & [46] \\
\hline
\end{tabular}




\section{Hijacking Insect Host Defenses and Pathogenesis by Liberibacter}

\subsection{Invasion}

The insect midgut serves as a major barrier that bacterial cells have to breach in order to continue and complete their pathway toward salivary glands. After ingestion by psyllids and reaching the midgut, the primary step for liberibacter infection requires focal adhesion to the midgut epithelial cells, followed by cellular invasion through endocytosis or membrane disruption. The molecular cross-talk mediated by host-pathogen protein-protein interactions is thought to play a key role in the disruption of host networks, followed by infection. Bacterial pathogens are known to possess adhesins and various outer membrane proteins that can bind to host membrane integrins for initial binding, thereby inducing invasion [47-49]. Transcriptome analysis of CLso infected B. trigonica show an induced expression of focal adhesion genes encoding for integrin, vinculin, paxillin, and cadherin, which act as receptors for pathogens [1]. On the contrary, papilin (involved in basal membrane formation), along with echinoid (transmembrane cell adhesion protein, involved in cell sorting), integrin, and fibrilins, were found to be downregulated in CLas infected D. ctri adults [50]. Annexin, another protein involved in endocytosis-mediated-invasion was upregulated in CLso-infected B. cockerelli [51]. CLso infected B. trigonica, and the transcriptome also showed elevated levels of adaptin and clathrin, indicating endocytosis after initial attachment [1].

\subsection{Infection}

After invasion, liberibacter must occupy a suitable niche in the epithelial cells in order to avoid host defenses and to successfully infect as many neighboring cells and finally reach the hemolymph for successful dissemination in the insect. CLas and CLso have been reported to utilize host cell endoplasmic reticulum (ER) for multiplication, inducing genes involved in the ER-associated protein degradation (ERAD) pathway such as Derlin-1, ER degradation-enhancing $\alpha$-mannosidase-like protein-2 (EDEM-2), ring finger protein 185 (E3 ligase RNF-185), Selenoprotein-1 (Sel1), ubiquitin conjugating enzyme, and ubiquitin ligase synoviolin A (Hrd1) [1,29,52]. Dense arrangement of ER was monitored around CLas containing vacuoles in D. citri esophagus, gut cells, and salivary glands [52-54]. Such phenomena might explain the elevated ER stress and ERAD in liberibacter-infected psyllids. CLso has also been found along the actin filaments in the potato psyllid midguts [55], and the overexpression of actin-related proteins in CLso infected B. trigonica [1] also indicates that liberibacter could manipulate host actin cytoskeleton for movement and dissemination. Additionally, CLas effectors could interact with hemocytin to modulate circulation in the hemolymph so as to systemically infect the host [51].

\subsection{Pathogenicity}

Phloem-inhabiting bacterial phytopathogens have smaller genomes than other phytopathogens [56]. Liberibacter species also have reduced genomes (Table 1) and show a lack of DNA repair genes, and depend both on their psyllid or plant host for essential metabolic functions and nutritional requirements [42-44,57]. Exploiting host proteins for survival and multiplication is a common behavior for systemic spread [50,58,59]. Virulence factors or effectors are generally secreted by bacterial pathogens for successful establishment in the host. There are several known CLas effectors secreted in plant cells, such as Las $A_{I}$ and Las $A_{I I}$ as autotransporters [60], LdtR for osmotic tolerance [61], Las5315 [62-65], and many more. Surprisingly, psyllid-liberibacter protein-protein interactions have not been studied enough. Gram-negative bacteria generally have injectosomes known as secretion systems through which they inject effector proteins into the host cells. CLas and CLso haplotype D are known to have an incomplete Type III and Type IV, but possess Type I secretion system (T1SS) and all the basic components of the Sec machinery $[45,64,66,67]$. The components of Sec machinery such as SecA, SecB, SecE, SecY, and SecD are conserved in all the sequenced CLso haplotypes. Moreover, CLas and CLso both possess flagella-like appendages and flagellar motor proteins, which might serve as an effector secretion system $[51,56,68,69]$. 
Protein-protein interactions are the functional interface in understanding host pathogen interactions, as depicted in Figure 1. Thus, evaluating the host-pathogen protein interactome could provide valuable insights into the biological functions and mechanisms of the virulence factor proteins leading to disease progression and spread. A lot more is yet to be unrevealed in the case of psyllid-liberibacter molecular interactions, which would improve our overall understanding the molecular basis of its pathogenicity.

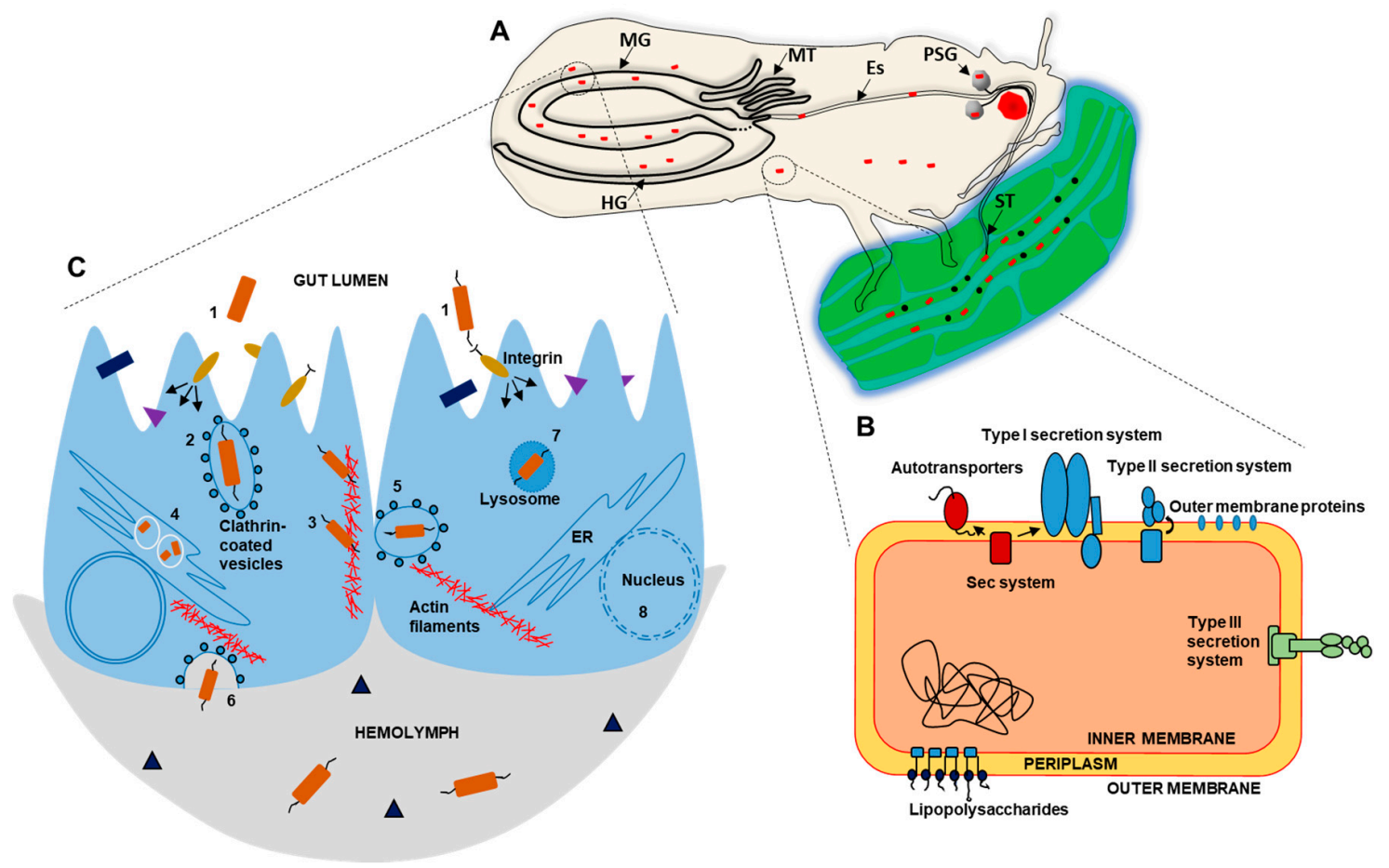

Figure 1. Schematic illustration depicting the major proteins and processes involved in psyllid-liberibacter interaction. (A) General internal anatomy of a psyllid during feeding on a plant leaf, specifically acquiring liberibacter from the phloem (red particles) and not the other particles (black dots), and also showing the midgut (MG), hindgut (HG), malpighian mubules (MT), esophgus (Es), primary salivary glands (PSG), and stylet (ST). (B) Known protein secretion systems of liberibacters, and $(C)$ liberibacter invasion and manipulation of host cell factors needed for dissemination inside the psyllid. (B) Liberibacters are known to have all the Sec dependent protein secretory systems, including autotransporters, Type I secretion system (T1SS), and Type II secretion system (T2SS), together with the incomplete Type III secretion system (T3SS) associated with the flagella as a Sec-independent secretion pathway. Initial attachment through these systems (adhesins and T3SS) initiates the secretion of the virulence factors and effectors. (C) Once the bacterium binds to the host cell through integrins and vinculins, (1) it initiates an essential signal cascade helping it to be endocytosed (2) by clathrin-coated vesicles. Once released in the host cytosol, the bacteria manipulates the host actin cytoskeleton for locomotion (3). Liberibacters find a suitable niche in the host ER, and recruit ER membrane structures to form vacuoles (4) for multiplication and avoiding host immunity. Using host cytoskeleton, liberibacters are engulfed by the neighbouring cells (5) for cell-to-cell spread. Finally, after exocytosis, it reaches the hemolymph (6) where it circulates and can reach the salivary glands for transmission. However, liberibacters cannot always escape host immunity with induced apoptosis (host cell death) by engulfment of the bacteria inside the lysosomes (7) and nuclear disintegration (8).

\section{Physiological Changes and Host Factors upon Infection}

Vector-borne pathogens are often less deleterious to their vectors than to their final plant or animal hosts [70,71], but liberibacter species seem to have detrimental effects on psyllids. The physiological changes often include internal physical damage in the midguts [29] and a decline in psyllid fecundity 
and nymph survival in response to liberibacters [70,72]. CLas-infected D. citri nymphs are also reported to develop faster than uninfected ones [72,73]. On the contrary, females are reported to invest more in immune response and survival to maintain long term reproductive viability, which causes increased oviposition for liberibacter-infected psyllids, however with reduced nymphal development and adult survivability $[73,74]$.

\subsection{Pathogen-Triggered Host Susceptibility}

Following acquisition, liberibacter colonizes the midgut epithelial cells, a process that induces programmed cell death (apoptosis) and endoplasmic reticulum-associated degradation (ERAD). The exact role of ERAD in the pathogenesis of liberibacters is still unknown, but psyllids undergo high ER stress and elevated unfolded protein response (UPR) upon liberibacter infection in order to restore ER homeostasis $[1,29,53]$. Fragmented chromatin, abnormal nuclei structures, and fragmented cells are some typical phenotypes observed in the psyllid midgut cells in response to liberibacter infection. An increase in actin bundling is also observed in the midguts of liberibacter infected D. citri and potato psyllid, B. cockerelli $[29,30,75]$.

Despite reduced genomic immune capacity, psyllids possess robust cellular immune defenses and utilize endosymbiont-derived defenses. The presence of CLas in D. citri was correlated with changes in endosymbiont populations. Increased populations of Wolbachia pipientis and reduced populations of Candidatus Carsonella rudii were observed in CLas-infected psyllids [76-78]. Candidatus Profftella armature, which is known to be involved in defense responses, produces a cytotoxic protein called Diaphorin, which is significantly decreased in CLas-infected D. citri adults $[79,80]$.

\subsection{Pathogen-Triggered Host Immunity}

Insect immunity is usually controlled by three signaling pathways. The Toll pathway in response to Gram-positive bacteria, fungi, and viruses [81-83]; the immune deficiency (Imd) pathway in response to Gram-negative bacteria [81,84]; and the Jak/STAT pathway in response to cytokines [85]. However, hemipterans have a reduced innate immunity and lack the Imd pathway $[50,84,86-88]$. The reduced response to Gram-negative bacteria could facilitate the acquisition of liberibacter in psyllids. Cellular innate immune responses (pathogen recognition by pattern-recognition receptors (PRR) and the activation of phagocytic cells) have been known to play a more important role in psyllids than inducible humoral responses (production of antimicrobial peptides) [80,87]. Moreover, as previously mentioned, psyllid immunity also differs within the developmental stages, and nymphs generally have reduced immunity compared with the adults. Psyllid transcriptome and proteome studies have revealed a number of upregulated defense-related genes in response to liberibacter infection (Figure 1). Apolipophorins, lipophorin receptors, vitellogenins, hemocyanin, aquaporins, fatty acid binding proteins (FABP), and peptidoglycan recognition proteins (PGRPs) are most commonly upregulated in D. citri in response to CLas. Catalase and copper zinc superoxide dismutase were one of the most abundant $D$. citri proteins present within the infected hemolymph $[75,80]$. The downregulation of tenascin and semaphorin involved in axon guidance and immunity, along with $\mathrm{ABC}$ transporters in the liberibacter-infected psyllids, might prevent liberibacter from interfering with host membrane transport [50]. Interestingly, vitellogenin, responsible for the vertical transmission of many vector-borne pathogens [89], is noted to be upregulated in almost all of the psyllid vectors harboring liberibacter, despite the low rate of transovarial transmission $[1,50,51,75,90]$. Vitellogenin is supposed to facilitate immune priming, have an antimicrobial activity, and elicit anti-oxidative protection in insects [91]. Another group of proteins involved in autophagy, such as Cathepsin B and syntaxin, and proteins involved in apoptosis, such as caspases, are highly expressed in B. trigonica midguts in response to CLso infection and in D. citri in response to CLas $[1,50,51,75]$. Signaling proteins, such as Rho family GTPases, operate as molecular switches to regulate immunity, gene transcription, cell cycle progression, and actin dynamics. Rac1, Jun N-terminus kinase (JNK)-like, and mitogen-activated protein kinase kinase (MAKK)-like genes are upregulated in D. citri in response to CLas [50]. These proteins are 
known to regulate apoptosis, cell proliferation, and stress responses to counteract liberibacter invasion. All of the possible known host factors in response to liberibacter are depicted in Figure 1.

\section{Disease Control and Disrupting Transmission}

Insecticide sprays are the major approach used today to prevent the economic damage caused by insects and vector-borne diseases [92,93]. However, insecticides, are harmful to humans, the environment, and beneficial organisms. In addition, insects develop resistance that hampers their effective and sustainable containment [94-98]. Genetically modified crops with introduced insecticidal agents have been used as an alternative to evade diseases caused by liberibacters. Transgenic citrus plants and Arabidopsis overexpressing NPR1, $\beta$-caryophyllene, and attacinA have shown enhanced resistance against $D$. citri [99-101]. However, the lack of approval for GM crops in various countries has raised the need for other alternatives [102]. Understanding the vector-pathogen transmission mechanism is an important step to limit or manage insect-mediated disease transmission, and has been suggested as a target for disease control. Disrupting the protein-protein interactions that affect pathogen invasion or multiplication in the insect vector could help reduce or prevent transmission [102].

\subsection{Host-Induced Gene Silencing}

RNA interference (RNAi) has become one of the major methods to explore gene functions underlying host-pathogen interactions and interactions between insect and pathogen proteins that have major roles in the transmission. RNAi targeting insect genes by using stable transgenic plants, also known as host-induced gene silencing (HIGS), have been a new generation of gene silencing methods for making plants resistant to insect-borne pathogens [103-109]. This approach requires knowledge of the molecular patterns involved in plant-pest interactions, and has been used as an effective approach in controlling crop diseases. HIGS requires small RNA production in the host plants to silence targeted pests or pathogens during their interaction. HIGS has been proposed to be successfully used in agriculture against several pathogenic microbes and arthropods by silencing gene functions, and is often referred to as RNAi biocides [110-117]. A similar example from psyllids is the study with B. cockerelli feeding on plants with RNAi against osmoregulatory genes, which showed significant mortality rates after feeding on the RNAi plants [118].

\subsection{Virus-Induced Gene Silencing}

In the last decade, virus-induced gene silencing (VIGS) technology was further developed for research and commercial use in agriculture. As most plant viruses utilize phloem tissues for systemic spread within plants and specifically RNA virus infection results in double stranded RNA, which acts as RNAi drivers, these viruses have often been used to target psyllids to disrupt molecular processes in insect cells [119-121]. For example, recombinant tobacco mosaic virus (TMV) has been used to induce RNAi via the plant expression for B. cockerelli as an alternative to transgenic approaches [119]. Another plant virus, Citrus tristeza virus (CTV), also accumulates abundant double-stranded RNA (dsRNA) and enormous amounts of siRNA as a result of antiviral silencing [122,123]. Oral delivery of CTV dsRNA and siRNA, as well as plant mediated delivery, induce eminent RNAi effects in B. cockerelli [123-125].

\subsection{Paratransgenesis}

Another variation of host-induced gene silencing (HIGS) using viruses and bacteria, is known as paratransgenic approach, which might be a promising tool to manage liberibacter transmission. The idea is to manipulate psyllid endosymbionts $[77,126,127]$ or use psyllid-specific viruses, such as densoviruses, which can be used as VIGS for foreign gene expression in the insect after manipulating the bacterial or viral endosymbionts $[128,129]$. This approach can provide an alternative and specific opportunity once the associations between these endosymbionts and the insects are unraveled. Reports of psyllid infecting viruses could be a potential tool to disrupt liberibacter transmission [130,131]. D. citri, for example, is known to harbor several viruses, including Diaphorina citri-associated C virus 
(DcACV), Diaphorina citri densovirus (DcDNV), Diaphorina citri reovirus (DcRV), Diaphorina citri flavi-like virus (DcFLV), and Diaphorina citri picorna-like virus (DcPLV) [132]. These viruses provide the basis for engineered vectors, which could improve the delivery of interfering RNA molecules to the psyllids, for targeting the insect proteins implicated in pathogen transmission.

Bacteria-mediated RNAi (bmRNAi) is another variation of a paratransgenic approach wherein engineered endosymbiotic bacteria expressing targeted dsRNA is allowed to colonize the insect while successfully competing with the wild microflora in the insect, resulting in the systemic knockdown of the targeted gene that is also horizontally transmissible [133-136].

\subsection{Nanoparticles and Using Clustered Regularly Interspaced Short Palindromic Repeats (CRISPR)}

Other novel non-transgenic delivery technologies, including peptide-based delivery vehicles, polymer or liposomic nanoparticles, and viral-like particles, also could be effective RNAi-based mechanisms to disrupt pathogen transmission. Peptide-based nano-assemblies, such as branched amphiphilic peptide capsules (BAPC), which are self-assembling peptide nano-capsular spheres, are also being used as a delivery vehicle for dsRNAs in insects [129,137]. Finally, CRISPR-based gene editing might modulate insect-host response to liberibacter infection. Injecting CRISPR/Cas9 components directly into nymphs and adults have shown heritable germline gene editing in subsequent generations in D. citri $[137,138]$.

Hence, there are unprecedented opportunities for providing long-term management solutions for liberibacters within the vector itself (Figure 2). Focusing on the molecular interactions between the psyllids and liberibacters might provide much more insights into disease management strategies.

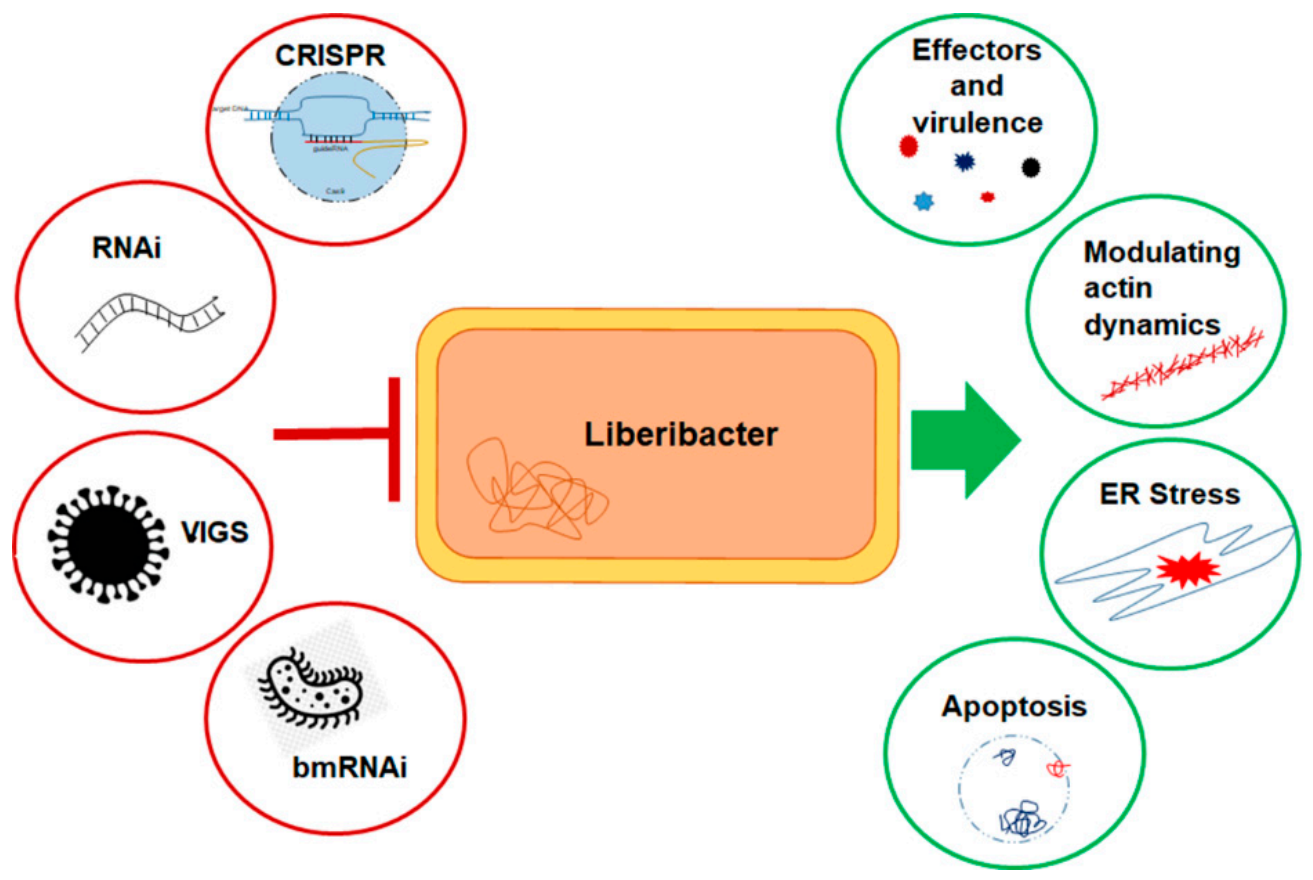

Figure 2. Simplified depiction of the novel strategies to inhibit Liberibacter infection and its effects on the insect host. Liberibacter modulates host cellular mechanisms in various mechanisms for successful dissemination and transmission, often leading to host cell damage (green circles). Multiple tools can be designed (red circles) to disrupt liberibacter-psyllid interactions as an effective management strategy.

\section{Conclusions and Perspective}

Liberibacters are insect-borne plant pathogens relying mainly on the insect vector for survival and spread, and represent an escalating threat for the production of citrus and many other crops worldwide. Liberibacters, as all other insect-borne pathogenic bacteria, manipulates insect-host defenses by 
secreting effector proteins which thereby helps them for proliferation and further transmission to the economically important crop plants. There is a constant battle for the pathogens to escape the host defenses and to find a way for survival and spread. This includes the secretion of virulence factors by Sec machinery to lower host defense, binding host proteins (such as actin related proteins) for spread within the hemolymph, finding a suitable niche to replicate and to avoid phagocytosis and ERAD, and many more. A much better understanding of the insect-pathogen interactions are needed, which would make it possible to predict better targeted strategies. The studies available provide us with enormous opportunities (RNAi, CRISPR, and paratransgenesis) to manage to disrupt the transmission at a basal level. In this review, we discuss the known liberibacter effectors, host defenses, and the major protein-protein interactions in order to decipher novel disease management strategies and use them to block the basal insect-liberibacter interaction, thereby disrupting transmission.

Author Contributions: P.S. prepared the original draft of the manuscript. M.G. raised the funding, and designed, wrote, and submitted the final version of the manuscript. All authors have read and agreed to the published version of the manuscript.

Funding: This research was supported by grant number 1163/18 from Israel Science Foundation (ISF) to M.G.

Acknowledgments: We wish to thank members in the Ghanim lab for fruitful discussions on the preliminary drafts of this review.

Conflicts of Interest: The authors declare no conflict of interest. The funders had no role in the design of the study; in the collection, analyses, or interpretation of data; in the writing of the manuscript; or in the decision to publish the results.

\section{References}

1. Ghosh, S.; Jassar, O.; Kontsedalov, S.; Lebedev, G.; Wang, C.; Turner, D.; Levy, A.; Ghanim, M. A Transcriptomics Approach Reveals Putative Interaction of Candidatus Liberibacter Solanacearum with the Endoplasmic Reticulum of Its Psyllid Vector. Insects 2019, 10, 279. [CrossRef] [PubMed]

2. Wang, N.; Pierson, E.A.; Setubal, J.C.; Xu, J.; Levy, J.G.; Zhang, Y.; Li, J.; Rangel, L.T.; Martins, J. The Candidatus Liberibacter-Host Interface: Insights into Pathogenesis Mechanisms and Disease Control. Annu. Rev. Phytopathol. 2017, 55, 451-482. [CrossRef] [PubMed]

3. Haapalainen, M. Biology and epidemics of Candidatus Liberibacter species, psyllid-transmitted plant-pathogenic bacteria. Ann. Appl. Biol. 2014, 165, 172-198. [CrossRef]

4. Casteel, C.L.; Hansen, A.K.; Walling, L.L.; Paine, T.D. Manipulation of plant defense responses by the tomato psyllid (Bactericerca cockerelli) and its associated endosymbiont Candidatus Liberibacter psyllaurous. PLoS ONE 2012, 7, e35191. [CrossRef]

5. Hansen, A.K.; Trumble, J.T.; Stouthamer, R.; Paine, T.D. A new huanglongbing species, "Candidatus Liberibacter psyllaurous," found to infect tomato and potato, is vectored by the psyllid Bactericera cockerelli (Sulc). Appl. Environ. Microbiol. 2008, 74, 5862-5865. [CrossRef]

6. Purcell, A.H. Insect vector relationships with procaryotic plant pathogens. Annu. Rev. Phytopathol. 1982, 20, 397-417. [CrossRef]

7. Gottwald, T.R.; Graham, J.H.; Irey, M.S.; McCollum, T.G.; Wood, B.W. Inconsequential effect of nutritional treatments on huanglongbing control, fruit quality, bacterial titer and disease progress. Crop. Prot. 2012, 36, 73-82. [CrossRef]

8. Bové, J.M. Huanglongbing: A destructive, newly-emerging, century-old disease of citrus. J. Plant Pathol. 2006, 88, 7-37.

9. Da Graca, J.V. Citrus greening disease. Annu. Rev. Phytopathol. 1991, 29, 109-136. [CrossRef]

10. Da Graça, J.V.; Korsten, L. Citrus huanglongbing: Review, present status and future strategies. In Diseases of Fruits and Vegetables; Springer: Berlin/Heidelberg, Germany, 2004; Volume I, pp. 229-245.

11. Do Carmo Teixeira, D.; Danet, J.L.; Eveillard, S.; Martins, E.C.; de Jesus Junior, W.C.; Yamamoto, P.T.; Lopes, S.A.; Bassanezi, R.B.; Ayres, A.J.; Saillard, C. Citrus huanglongbing in Sao Paulo State, Brazil: PCR detection of the 'Candidatus' Liberibacter species associated with the disease. Mol. Cell. Probes 2005, 19, 173-179. [CrossRef] 
12. Texeira, D.D.C.; Ayres, J.; Kitajima, E.W.; Danet, L.; Jagoueix-Eveillard, S.; Saillard, C.; Bové, J.M. First report of a huanglongbing-like disease of citrus in São Paulo State, Brazil and association of a new Liberibacter species, "Candidatus Liberibacter americanus", with the disease. Plant Dis. 2005, 89, 107. [CrossRef] [PubMed]

13. Abad, J.A.; Bandla, M.; French-Monar, R.D.; Liefting, L.W.; Clover, G.R.G. First report of the detection of 'Candidatus Liberibacter'species in zebra chip disease-infected potato plants in the United States. Plant Dis. 2009, 93, 108. [CrossRef] [PubMed]

14. Zhao, Z.; Prager, S.M.; Cruzado, R.K.; Liang, X.; Cooper, W.R.; Hu, G.; Rashed, A. Characterizing Zebra Chip Symptom Severity and Identifying Spectral Signatures Associated with 'Candidatus Liberibacter solanacearum'-Infected Potato Tubers. Am. J. Potato Res. 2018, 95, 584-596. [CrossRef]

15. Munyaneza, J.E.; Crosslin, J.M.; Upton, J.E. Association of Bactericera cockerelli (Homoptera: Psyllidae) with "zebra chip," a new potato disease in southwestern United States and Mexico. J. Econ. Entomol. 2007, 100, 656-663. [CrossRef]

16. Munyaneza, J.E. Zebra chip disease of potato: Biology, epidemiology, and management. Am. J. Potato Res. 2012, 89, 329-350. [CrossRef]

17. McClean, A.P.D.; Oberholzer, P.C.J. Citrus psylla, a vector of the greening disease of sweet orange. S. Afr. J. Agric. Sci. 1965, 8, 297-298.

18. Ammar, E.-D.; Ramos, J.E.; Hall, D.G.; Dawson, W.O.; Shatters, R.G., Jr. Acquisition, replication and inoculation of Candidatus Liberibacter asiaticus following various acquisition periods on huanglongbing-infected citrus by nymphs and adults of the Asian citrus psyllid. PLOS ONE 2016, 11, e0159594. [CrossRef]

19. Tirtawidjaja, S. Citrus vein phloem degeneration virus, a possible cause of citrus chlorosis in Java. Proc. Am. Soc. Hortic. Sci. 1965, 86, 235-243.

20. Catling, H.D. Distribution of the psyllid vectors of citrus greening disease, with notes on the biology and bionomics of Diaphorina citri. FAO Plant Prot. Bull. 1970, 18, 8-15.

21. Capoor, S.P.; Rao, D.G.; Viswanath, S.M. Greening disease of citrus in the Deccan Trap Country and its relationship with the vector, Diaphorina citri Kuwayama. In International Organization of Citrus Virologists Conference Proceedings (1957-2010); eScholarship: Riverside, CA, USA, 1974; Volume 6, p. 6.

22. Fagen, J.R.; Leonard, M.T.; Coyle, J.F.; McCullough, C.M.; Davis-Richardson, A.G.; Davis, M.J.; Triplett, E.W. Liberibactercrescens gen. nov., sp. nov., the first cultured member of the genus Liberibacter. Int. J. Syst. Evol. Microbiol. 2014, 64, 2461-2466. [CrossRef]

23. Ammar, E.-D.; Shatters, R.G., Jr.; Lynch, C.; Hall, D.G. Detection and relative titer of Candidatus Liberibacter asiaticus in the salivary glands and alimentary canal of Diaphorina citri (Hemiptera: Psyllidae) vector of citrus huanglongbing disease. Ann. Entomol. Soc. Am. 2011, 104, 526-533. [CrossRef]

24. Mawassi, M.; Dror, O.; Bar-Joseph, M.; Piasezky, A.; Sjölund, J.M.; Levitzky, N.; Shoshana, N.; Meslenin, L.; Haviv, S.; Porat, C.; et al. 'Candidatus Liberibacter solanacearum' Is Tightly Associated with Carrot Yellows Symptoms in Israel and Transmitted by the Prevalent Psyllid Vector Bactericera trigonica. Phytopathology 2018, 108, 1056-1066. [CrossRef] [PubMed]

25. Pelz-Stelinski, K.S.; Brlansky, R.H.; Ebert, T.A.; Rogers, M.E. Transmission parameters for Candidatus Liberibacter asiaticus by Asian citrus psyllid (Hemiptera: Psyllidae). J. Econ. Entomol. 2010, 103, 1531-1541. [CrossRef] [PubMed]

26. Ammar, E.; Shatters, R.G., Jr.; Hall, D.G. Localization of Candidatus Liberibacter asiaticus, associated with citrus huanglongbing disease, in its psyllid vector using fluorescence in situ hybridization. J. Phytopathol. 2011, 159, 726-734. [CrossRef]

27. Luo, X.; Yen, A.L.; Powell, K.S.; Wu, F.; Wang, Y.; Zeng, L.; Yang, Y.; Cen, Y. Feeding behavior of Diaphorina citri (Hemiptera: Liviidae) and its acquisition of'Candidatus Liberibacter asiaticus', on huanglongbing-infected Citrus reticulata leaves of several maturity stages. Fla. Entomol. 2015, 98, 186-192. [CrossRef]

28. Canale, M.C.; Tomaseto, A.F.; de Haddad, M.L.; Della Coletta-Filho, H.; Lopes, J.R.S. Latency and persistence of 'Candidatus Liberibacter asiaticus' in its psyllid vector, Diaphorina citri (Hemiptera: Liviidae). Phytopathology 2017, 107, 264-272. [CrossRef]

29. Ghanim, M.; Fattah-Hosseini, S.; Levy, A.; Cilia, M. Morphological abnormalities and cell death in the Asian citrus psyllid (Diaphorina citri) midgut associated with Candidatus Liberibacter asiaticus. Sci. Rep. 2016, 6, 33418. [CrossRef] 
30. Mann, M.; Fattah-Hosseini, S.; Ammar, E.-D.; Stange, R.; Warrick, E.; Sturgeon, K.; Shatters, R.; Heck, M. Diaphorina citri nymphs are resistant to morphological changes induced by "Candidatus Liberibacter asiaticus" in midgut epithelial cells. Infect. Immun. 2018, 86, e00889-17. [CrossRef]

31. Kelley, A.J.; Pelz-Stelinski, K.S. Maternal contribution of Candidatus Liberibacter asiaticus to Asian citrus psyllid (Hemiptera: Liviidae) nymphs through oviposition site inoculation and transovarial transmission. J. Econ. Entomol. 2019, 112, 2565-2568. [CrossRef]

32. Mann, R.S.; Pelz-Stelinski, K.; Hermann, S.L.; Tiwari, S.; Stelinski, L.L. Sexual transmission of a plant pathogenic bacterium, Candidatus Liberibacter asiaticus, between conspecific insect vectors during mating. PLOS ONE 2011, 6, e29197. [CrossRef]

33. Inoue, H.; Ohnishi, J.; Ito, T.; Tomimura, K.; Miyata, S.; Iwanami, T.; Ashihara, W. Enhanced proliferation and efficient transmission of Candidatus Liberibacter asiaticus by adult Diaphorina citri after acquisition feeding in the nymphal stage. Ann. Appl. Biol. 2009, 155, 29-36. [CrossRef]

34. George, J.; Ammar, E.-D.; Hall, D.G.; Shatters, R.G.; Lapointe, S.L. Prolonged phloem ingestion by Diaphorina citri nymphs compared to adults is correlated with increased acquisition of citrus greening pathogen. Sci. Rep. 2018, 8, 1-11. [CrossRef] [PubMed]

35. Ramsey, J.S.; Chavez, J.D.; Johnson, R.; Hosseinzadeh, S.; Mahoney, J.E.; Mohr, J.P.; Robison, F.; Zhong, X.; Hall, D.G.; MacCoss, M. Protein interaction networks at the host-microbe interface in Diaphorina citri, the insect vector of the citrus greening pathogen. R. Soc. Open Sci. 2017, 4, 160545. [CrossRef] [PubMed]

36. Xu, C.F.; Xia, Y.H.; Li, K.B.; Ke, C. Further study of the transmission of citrus huanglungbin by a psyllid, Diaphorina citri Kuwayama. In International Organization of Citrus Virologists Conference Proceedings (1957-2010); eScholarship: Riverside, CA, USA, 1988; Volume 10, p. 10.

37. Cooper, W.R.; Sengoda, V.G.; Munyaneza, J.E. Localization of 'Candidatus Liberibacter solanacearum'(Rhizobiales: Rhizobiaceae) in Bactericera cockerelli (Hemiptera: Triozidae). Ann. Entomol. Soc. Am. 2014, 107, 204-210. [CrossRef]

38. Sengoda, V.G.; Cooper, W.R.; Swisher, K.D.; Henne, D.C.; Munyaneza, J.E. Latent period and transmission of "Candidatus Liberibacter solanacearum" by the potato psyllid Bactericera cockerelli (Hemiptera: Triozidae). PLoS ONE 2014, 9, e93475. [CrossRef]

39. Leonard, M.T.; Fagen, J.R.; Davis-Richardson, A.G.; Davis, M.J.; Triplett, E.W. Complete genome sequence of Liberibacter crescens BT-1. Stand. Genom. Sci. 2012, 7, 271-283. [CrossRef]

40. Duan, Y.; Zhou, L.; Hall, D.G.; Li, W.; Doddapaneni, H.; Lin, H.; Liu, L.; Vahling, C.M.; Gabriel, D.W.; Williams, K.P. Complete genome sequence of citrus huanglongbing bacterium,'Candidatus Liberibacter asiaticus' obtained through metagenomics. Mol. Plant-Microbe Interact. 2009, 22, 1011-1020. [CrossRef]

41. Lin, H.; Pietersen, G.; Han, C.; Read, D.A.; Lou, B.; Gupta, G.; Civerolo, E.L. Complete genome sequence of "Candidatus Liberibacter africanus," a bacterium associated with citrus huanglongbing. Genome Announc. 2015, 3, e00733-15. [CrossRef]

42. Wulff, N.A.; Zhang, S.; Setubal, J.C.; Almeida, N.F.; Martins, E.C.; Harakava, R.; Kumar, D.; Rangel, L.T.; Foissac, X.; Bové, J.M. The complete genome sequence of 'Candidatus Liberibacter americanus', associated with citrus huanglongbing. Mol. Plant-Microbe Interact. 2014, 27, 163-176. [CrossRef]

43. Lin, H.; Lou, B.; Glynn, J.M.; Doddapaneni, H.; Civerolo, E.L.; Chen, C.; Duan, Y.; Zhou, L.; Vahling, C.M. The complete genome sequence of 'Candidatus Liberibacter solanacearum', the bacterium associated with potato zebra chip disease. PLoS ONE 2011, 6, e19135. [CrossRef]

44. Wang, J.; Haapalainen, M.; Schott, T.; Thompson, S.M.; Smith, G.R.; Nissinen, A.I.; Pirhonen, M. Genomic sequence of "Candidatus Liberibacter solanacearum" haplotype C and its comparison with haplotype A and B genomes. PLoS ONE 2017, 12, e0171531. [CrossRef] [PubMed]

45. Katsir, L.; Zhepu, R.; Garcia, D.S.; Piasezky, A.; Jiang, J.; Smith, G.R. Genome Analysis of Haplotype D of Candidatus Liberibacter Solanacearum. Front. Microbiol. 2018, 9, 1-13. [CrossRef] [PubMed]

46. Frampton, R.A.; Thompson, S.M.; Kalamorz, F.; David, C.; Addison, S.M.; Smith, G.R. Draft genome sequence of a "Candidatus Liberibacter europaeus" strain assembled from broom psyllids (Arytainilla spartiophila) from New Zealand. Genome Announc. 2018, 6, e00430-18. [CrossRef] [PubMed]

47. Ulanova, M.; Gravelle, S.; Barnes, R. The role of epithelial integrin receptors in recognition of pulmonary pathogens. J. Innate Immun. 2009, 1, 4-17. [CrossRef]

48. Vallet-Gely, I.; Lemaitre, B.; Boccard, F. Bacterial strategies to overcome insect defences. Nat. Rev. Microbiol. 2008, 6, 302-313. [CrossRef] 
49. Nicod, C.; Banaei-Esfahani, A.; Collins, B.C. Elucidation of host-pathogen protein-protein interactions to uncover mechanisms of host cell rewiring. Curr. Opin. Microbiol. 2017, 39, 7-15. [CrossRef]

50. Vyas, M.; Fisher, T.W.; He, R.; Nelson, W.; Yin, G.; Cicero, J.M.; Willer, M.; Kim, R.; Kramer, R.; May, G.A. Asian citrus psyllid expression profiles suggest Candidatus Liberibacter asiaticus-mediated alteration of adult nutrition and metabolism, and of nymphal development and immunity. PLoS ONE 2015, 10, e0130328. [CrossRef]

51. Fisher, T.W.; Vyas, M.; He, R.; Nelson, W.; Cicero, J.M.; Willer, M.; Kim, R.; Kramer, R.; May, G.A.; Crow, J.A.; et al. Comparison of potato and asian citrus psyllid adult and nymph transcriptomes identified vector transcripts with potential involvement in circulative, propagative liberibacter transmission. Pathogens 2014, 3, 875-907. [CrossRef]

52. Ammar, E.-D.; Achor, D.; Levy, A. Immuno-Ultrastructural Localization and Putative Multiplication Sites of Huanglongbing Bacterium in Asian Citrus Psyllid Diaphorina citri. Insects 2019, 10, 422. [CrossRef]

53. Ghanim, M.; Achor, D.; Ghosh, S.; Kontsedalov, S.; Lebedev, G.; Levy, A. 'Candidatus Liberibacter asiaticus' Accumulates inside Endoplasmic Reticulum Associated Vacuoles in the Gut Cells of Diaphorina citri. Sci. Rep. 2017, 7, 16945. [CrossRef]

54. Ammar, E.-D.; Hall, D.G.; Shatters, R.G., Jr. Ultrastructure of the salivary glands, alimentary canal and bacteria-like organisms in the Asian citrus psyllid, vector of citrus huanglongbing disease bacteria. J. Microsc. Ultrastruct. 2017, 5, 9-20. [CrossRef] [PubMed]

55. Tang, X.-T.; Tamborindeguy, C. No evidence of apoptotic response of the potato psyllid, Bactericera cockerelli, to "Candidatus Liberibacter solanacearum" at the gut interface. Infect. Immun. 2019, 88, e00242-19. [CrossRef] [PubMed]

56. Fujiwara, K.; Iwanami, T.; Fujikawa, T. Alterations of Candidatus Liberibacter asiaticus-associated microbiota decrease survival of Ca. L. asiaticus in in vitro assays. Front. Microbiol. 2018, 9, 3089. [CrossRef] [PubMed]

57. Hartung, J.S.; Shao, J.; Kuykendall, L.D. Comparison of the "Ca. Liberibacter asiaticus" genome adapted for an intracellular lifestyle with other members of the Rhizobiales. PLoS ONE 2011, 6, e23289. [CrossRef] [PubMed]

58. Cambronne, E.D.; Roy, C.R. Recognition and delivery of effector proteins into eukaryotic cells by bacterial secretion systems. Traffic 2006, 7, 929-939. [CrossRef]

59. Dean, P. Functional domains and motifs of bacterial type III effector proteins and their roles in infection. FEMS Microbiol. Rev. 2011, 35, 1100-1125. [CrossRef]

60. Hao, G.; Boyle, M.; Zhou, L.; Duan, Y. The intracellular citrus Huanglongbing bacterium, 'Candidatus Liberibacter asiaticus' encodes two novel autotransporters. PLoS ONE 2013, 8, e68921. [CrossRef]

61. Pagliai, F.A.; Gardner, C.L.; Bojilova, L.; Sarnegrim, A.; Tamayo, C.; Potts, A.H.; Teplitski, M.; Folimonova, S.Y.; Gonzalez, C.F.; Lorca, G.L. The transcriptional activator LdtR from 'Candidatus Liberibacter asiaticus' mediates osmotic stress tolerance. PLoS Pathog. 2014, 10, e1004101. [CrossRef]

62. Shi, Q.; Pitino, M.; Zhang, S.; Krystel, J.; Cano, L.M.; Shatters, R.G.; Hall, D.G.; Stover, E. Temporal and spatial detection of Candidatus Liberibacter asiaticus putative effector transcripts during interaction with Huanglongbing-susceptible, -tolerant, and -resistant citrus hosts. BMC Plant Biol. 2019, 19, 122. [CrossRef]

63. Pitino, M.; Allen, V.; Duan, Y. Las $\Delta 5315$ Effector Induces Extreme Starch Accumulation and Chlorosis as Ca. Liberibacter asiaticus Infection in Nicotiana benthamiana. Front. Plant Sci. 2018, 9, 113. [CrossRef]

64. Pitino, M.; Armstrong, C.M.; Cano, L.M.; Duan, Y. Transient Expression of Candidatus Liberibacter Asiaticus Effector Induces Cell Death in Nicotiana benthamiana. Front. Plant Sci. 2016, 7, 982. [CrossRef] [PubMed]

65. Zhang, C.; Wang, X.; Liu, X.; Fan, Y.; Zhang, Y.; Zhou, X.; Li, W. A Novel 'Candidatus Liberibacter asiaticus'-Encoded Sec-Dependent Secretory Protein Suppresses Programmed Cell Death in Nicotiana benthamiana. Int. J. Mol. Sci. 2019, 20, 5802. [CrossRef] [PubMed]

66. Cong, Q.; Kinch, L.N.; Kim, B.-H.; Grishin, N.V. Predictive sequence analysis of the Candidatus Liberibacter asiaticus proteome. PLoS ONE 2012, 7, e41071. [CrossRef] [PubMed]

67. Li, B.; Yang, Y.; Luo, Z.; Liu, Z.; Yu, N. Quantitative Screening of secretory protein genes in Candidatus Liberibacter Asiaticus. Am. J. Plant Sci. 2018, 9, 2408. [CrossRef]

68. Andrade, M.O.; Pang, Z.; Achor, D.S.; Wang, H.; Yao, T.; Singer, B.H.; Wang, N. The flagella of 'Candidatus Liberibacter asiaticus' and its movement in planta. Mol. Plant Pathol. 2020, 21, 109-123. [CrossRef]

69. Coyle, J.F.; Lorca, G.L.; Gonzalez, C.F. Understanding the Physiology of Liberibacter asiaticus: An Overview of the Demonstrated Molecular Mechanisms. J. Mol. Microbiol. Biotechnol. 2018, 28, 116-127. [CrossRef] 
70. Nachappa, P.; Levy, J.; Pierson, E.; Tamborindeguy, C. Correlation between "Candidatus Liberibacter solanacearum" infection levels and fecundity in its psyllid vector. J. Invertebr. Pathol. 2014, 115, 55-61. [CrossRef]

71. McCombie, S. Evolution of infectious disease. By Paul W. Ewald. New York: Oxford University Press. 1994. ISBN 0-19-506058-X. 298 pp. \$35 (cloth). Am. J. Phys. Anthropol. 1994, 95, 244-246. [CrossRef]

72. Ren, S.; Li, Y.; Zhou, Y.; Xu, W.; Cuthbertson, A.G.S.; Guo, Y.; Qiu, B. Effects of Candidatus Liberibacter asiaticus on the fitness of the vector Diaphorina citri. J. Appl. Microbiol. 2016, 121, 1718-1726. [CrossRef]

73. Pelz-Stelinski, K.S.; Killiny, N. Better together: Association with 'Candidatus Liberibacter asiaticus' increases the reproductive fitness of its insect vector, Diaphorina citri (Hemiptera: Liviidae). Ann. Entomol. Soc. Am. 2016, 109, 371-376. [CrossRef]

74. Ebert, T.A. The Probing Behavior Component of Disease Transmission in Insect-Transmitted Bacterial Plant Pathogens. Insects 2019, 10, 212. [CrossRef] [PubMed]

75. Kruse, A.; Ramsey, J.S.; Johnson, R.; Hall, D.G.; MacCoss, M.J.; Heck, M. Candidatus Liberibacter asiaticus minimally alters expression of immunity and metabolism proteins in hemolymph of Diaphorina citri, the insect vector of Huanglongbing. J. Proteome Res. 2018, 17, 2995-3011. [CrossRef] [PubMed]

76. Fagen, J.R.; Giongo, A.; Brown, C.T.; Davis-Richardson, A.G.; Gano, K.A.; Triplett, E.W. Characterization of the relative abundance of the citrus pathogen Ca. Liberibacter asiaticus in the microbiome of its insect vector, Diaphorina citri, using high throughput 16S rRNA sequencing. Open Microbiol. J. 2012, 6, 29. [CrossRef] [PubMed]

77. Chu, C.-C.; Gill, T.A.; Hoffmann, M.; Pelz-Stelinski, K.S. Inter-population variability of endosymbiont densities in the Asian citrus psyllid (Diaphorina citri Kuwayama). Microb. Ecol. 2016, 71, 999-1007. [CrossRef]

78. Galdeano, D.M.; de Souza Pacheco, I.; Alves, G.R.; Granato, L.M.; Rashidi, M.; Turner, D.; Levy, A.; Machado, M.A. Friend or foe? Relationship between 'Candidatus Liberibacter asiaticus' and Diaphorina citri. In Tropical Plant Pathology; Springer: Berlin/Heidelberg, Germany, 2020.

79. Nakabachi, A.; Ueoka, R.; Oshima, K.; Teta, R.; Mangoni, A.; Gurgui, M.; Oldham, N.J.; van Echten-Deckert, G.; Okamura, K.; Yamamoto, K. Defensive bacteriome symbiont with a drastically reduced genome. Curr. Biol. 2013, 23, 1478-1484. [CrossRef]

80. Gill, T.A.; Chu, C.; Pelz-Stelinski, K.S. Comparative proteomic analysis of hemolymph from uninfected and Candidatus Liberibacter asiaticus-infected Diaphorina citri. Amino Acids 2017, 49, 389-406. [CrossRef]

81. Lemaitre, B.; Meister, M.; Govind, S.; Georgel, P.; Steward, R.; Reichhart, J.M.; Hoffmann, J.A. Functional analysis and regulation of nuclear import of dorsal during the immune response in Drosophila. EMBO J. 1995, 14, 536-545. [CrossRef]

82. Rutschmann, S.; Kilinc, A.; Ferrandon, D. Cutting edge: The toll pathway is required for resistance to gram-positive bacterial infections in Drosophila. J. Immunol. 2002, 168, 1542-1546. [CrossRef]

83. Zambon, R.A.; Nandakumar, M.; Vakharia, V.N.; Wu, L.P. The Toll pathway is important for an antiviral response in Drosophila. Proc. Natl. Acad. Sci. USA 2005, 102, 7257-7262. [CrossRef]

84. Nishide, Y.; Kageyama, D.; Yokoi, K.; Jouraku, A.; Tanaka, H.; Futahashi, R.; Fukatsu, T. Functional crosstalk across IMD and Toll pathways: Insight into the evolution of incomplete immune cascades. Proc. R. Soc. B 2019, 286, 20182207. [CrossRef]

85. Souza-Neto, J.A.; Sim, S.; Dimopoulos, G. An evolutionary conserved function of the JAK-STAT pathway in anti-dengue defense. Proc. Natl. Acad. Sci. USA 2009, 106, 17841-17846. [CrossRef] [PubMed]

86. Hillyer, J.F. Insect immunology and hematopoiesis. Dev. Comp. Immunol. 2016, 58, 102-118. [CrossRef] [PubMed]

87. Arp, A.P.; Martini, X.; Pelz-Stelinski, K.S. Innate immune system capabilities of the Asian citrus psyllid, Diaphorina citri. J. Invertebr. Pathol. 2017, 148, 94-101. [CrossRef] [PubMed]

88. Gerardo, N.M.; Altincicek, B.; Anselme, C.; Atamian, H.; Barribeau, S.M.; De Vos, M.; Duncan, E.J.; Evans, J.D.; Gabaldón, T.; Ghanim, M. Immunity and other defenses in pea aphids, Acyrthosiphon pisum. Genome Biol. 2010, 11, R21. [CrossRef]

89. Huo, Y.; Liu, W.; Zhang, F.; Chen, X.; Li, L.; Liu, Q.; Zhou, Y.; Wei, T.; Fang, R.; Wang, X. Transovarial transmission of a plant virus is mediated by vitellogenin of its insect vector. PLoS Pathog 2014, 10, e1003949. [CrossRef] 
90. Ibanez, F.; Tang, X.; Tamborindeguy, C. Bactericera cockerelli vitellogenin-6 like, a vitellogenin without a direct reproductive function? Insect. Mol. Biol. 2018, 27, 166-176. [CrossRef]

91. Kodrík, D.; Ibrahim, E.; Gautam, U.K.; Čapková Frydrychová, R.; Bednářová, A.; Krištůfek, V.; Jedlička, P. Changes in vitellogenin expression caused by nematodal and fungal infections in insects. J. Exp. Biol. 2019, 222, jeb202853. [CrossRef]

92. Page-Weir, N.E.M.; Jamieson, L.E.; Chhagan, A.; Connolly, P.G.; Curtis, C. Efficacy of insecticides against the tomato/potato psyllid (Bactericera cockerelli). N. Z. Plant Prot. 2011, 64, 276-281. [CrossRef]

93. Qureshi, J.A.; Kostyk, B.C.; Stansly, P.A. Insecticidal suppression of Asian citrus psyllid Diaphorina citri (Hemiptera: Liviidae) vector of huanglongbing pathogens. PLOS ONE 2014, 9, e112331. [CrossRef]

94. Tansey, J.A.; Vanaclocha, P.; Monzo, C.; Jones, M.; Stansly, P.A. Costs and benefits of insecticide and foliar nutrient applications to huanglongbing-infected citrus trees. Pest Manag. Sci. 2017, 73, 904-916. [CrossRef]

95. Guenthner, J.; Goolsby, J.; Greenway, G. Use and cost of insecticides to control potato psyllids and zebra chip on potatoes. Southwest. Entomol. 2012, 37, 263-270. [CrossRef]

96. Munyaneza, J.E. Zebra Chip Disease, Candidatus Liberibacter, and Potato Psyllid: A Global Threat to the Potato Industry. Am. J. Potato Res. 2015, 92, 230-235. [CrossRef]

97. Tiwari, S.; Killiny, N.; Mann, R.S.; Wenninger, E.J.; Stelinski, L.L. Abdominal color of the Asian citrus psyllid, Diaphorina citri, is associated with susceptibility to various insecticides. Pest Manag. Sci. 2013, 69, 535-541. [CrossRef] [PubMed]

98. Monzo, C.; Stansly, P.A. Economic injury levels for Asian citrus psyllid control in process oranges from mature trees with high incidence of huanglongbing. PLoS ONE 2017, 12, e0175333. [CrossRef] [PubMed]

99. Dutt, M.; Barthe, G.; Irey, M.; Grosser, J. Transgenic Citrus Expressing an Arabidopsis NPR1 Gene Exhibit Enhanced Resistance against Huanglongbing (HLB; Citrus Greening). PLoS ONE 2015, 10, e0137134. [CrossRef] [PubMed]

100. Alquézar, B.; Volpe, H.X.L.; Magnani, R.F.; de Miranda, M.P.; Santos, M.A.; Wulff, N.A.; Bento, J.M.S.; Parra, J.R.P.; Bouwmeester, H.; Peña, L. $\beta$-caryophyllene emitted from a transgenic Arabidopsis or chemical dispenser repels Diaphorina citri, vector of Candidatus Liberibacters. Sci. Rep. 2017, 7, 5639. [CrossRef] [PubMed]

101. Da Tavano, E.C.R.; Erpen, L.; Aluisi, B.; Harakava, R.; Lopes, J.R.S.; Vieira, M.L.C.; Piedade, S.M.D.S.; Mendes, B.M.J.; de Mourão Filho, F.A.A. Sweet orange genetic transformation with the attacin A gene under the control of phloem-specific promoters and inoculation with Candidatus Liberibacter asiaticus. J. Hortic. Sci. Biotechnol. 2019, 94, 210-219. [CrossRef]

102. Vereijssen, J.; Smith, G.R.; Weintraub, P.G. Bactericera cockerelli (Hemiptera: Triozidae) and Candidatus Liberibacter solanacearum in potatoes in New Zealand: Biology, transmission, and implications for management. J. Integr. Pest Manag. 2018, 9, 13. [CrossRef]

103. Rodrigues, T.B.; Figueira, A. Management of insect pest by RNAi-A new tool for crop protection. RNA Interf. 2016. [CrossRef]

104. Mamta, B.; Rajam, M.V. RNAi technology: A new platform for crop pest control. Physiol. Mol. Biol. Plants 2017, 23, 487-501. [CrossRef]

105. Cagliari, D.; Dias, N.P.; Galdeano, D.M.; Dos Santos, E.Á.; Smagghe, G.; Zotti, M.J. Management of Pest Insects and Plant Diseases by Non-Transformative RNAi. Front. Plant Sci. 2019, 10, 1319. [CrossRef] [PubMed]

106. Lundgren, J.G.; Duan, J.J. Potential Effects on Nontarget Species. Bioscience 2013, 63, 657-665. [CrossRef]

107. Liu, S.; Jaouannet, M.; Dempsey, D.A.; Imani, J.; Coustau, C.; Kogel, K.-H. RNA-based technologies for insect control in plant production. Biotechnol. Adv. 2020, 39, 107463. [CrossRef] [PubMed]

108. Price, D.R.G.; Gatehouse, J.A. RNAi-mediated crop protection against insects. Trends Biotechnol. 2008, 26, 393-400. [CrossRef] [PubMed]

109. Gordon, K.H.J.; Waterhouse, P.M. RNAi for insect-proof plants. Nat. Biotechnol. 2007, 25, 1231-1232. [CrossRef]

110. Huang, G.; Allen, R.; Davis, E.L.; Baum, T.J.; Hussey, R.S. Engineering broad root-knot resistance in transgenic plants by RNAi silencing of a conserved and essential root-knot nematode parasitism gene. Proc. Natl. Acad. Sci. USA 2006, 103, 14302-14306. [CrossRef]

111. Qi, T.; Guo, J.; Peng, H.; Liu, P.; Kang, Z.; Guo, J. Host-Induced Gene Silencing: A Powerful Strategy to Control Diseases of Wheat and Barley. Int. J. Mol. Sci. 2019, 20, 206. [CrossRef] 
112. Baum, J.A.; Bogaert, T.; Clinton, W.; Heck, G.R.; Feldmann, P.; Ilagan, O.; Johnson, S.; Plaetinck, G.; Munyikwa, T.; Pleau, M.; et al. Control of coleopteran insect pests through RNA interference. Nat. Biotechnol. 2007, 25, 1322-1326. [CrossRef]

113. Zhang, J.; Khan, S.A.; Hasse, C.; Ruf, S.; Heckel, D.G.; Bock, R. Full crop protection from an insect pest by expression of long double-stranded RNAs in plastids. Science 2015, 347, 991-994. [CrossRef]

114. Ghosh, S.K.B.; Hunter, W.B.; Park, A.L.; Gundersen-Rindal, D.E. Double strand RNA delivery system for plant-sap-feeding insects. PLoS ONE 2017, 12, e0171861. [CrossRef]

115. Koch, A.; Kumar, N.; Weber, L.; Keller, H.; Imani, J.; Kogel, K.-H. Host-induced gene silencing of cytochrome P450 lanosterol C14 $\alpha$-demethylase-encoding genes confers strong resistance to Fusarium species. Proc. Natl. Acad. Sci. USA 2013, 110, 19324-19329. [CrossRef] [PubMed]

116. Koch, A.; Biedenkopf, D.; Furch, A.; Weber, L.; Rossbach, O.; Abdellatef, E.; Linicus, L.; Johannsmeier, J.; Jelonek, L.; Goesmann, A. An RNAi-based control of Fusarium graminearum infections through spraying of long dsRNAs involves a plant passage and is controlled by the fungal silencing machinery. PLoS Pathog. 2016, 12, e1005901. [CrossRef] [PubMed]

117. Mitter, N.; Worrall, E.A.; Robinson, K.E.; Li, P.; Jain, R.G.; Taochy, C.; Fletcher, S.J.; Carroll, B.J.; Lu, G.Q.M.; $\mathrm{Xu}$, Z.P. Clay nanosheets for topical delivery of RNAi for sustained protection against plant viruses. Nat. Plants 2017, 3, 1-10. [CrossRef]

118. Tzin, V.; Yang, X.; Jing, X.; Zhang, K.; Jander, G.; Douglas, A.E. RNA interference against gut osmoregulatory genes in phloem-feeding insects. J. Insect Physiol. 2015, 79, 105-112. [CrossRef] [PubMed]

119. Wuriyanghan, H.; Falk, B.W. RNA interference towards the potato psyllid, Bactericera cockerelli, is induced in plants infected with recombinant tobacco mosaic virus (TMV). PLoS ONE 2013, 8, e66050. [CrossRef]

120. Kanakala, S.; Kontsedalov, S.; Lebedev, G.; Ghanim, M. Plant-Mediated Silencing of the Whitefly Bemisia tabaci Cyclophilin B and Heat Shock Protein 70 impairs insect development and virus transmission. Front. Physiol. 2019, 10, 557. [CrossRef]

121. Rosa, C.; Kuo, Y.-W.; Wuriyanghan, H.; Falk, B.W. RNA interference mechanisms and applications in plant pathology. Annu. Rev. Phytopathol. 2018, 56, 581-610. [CrossRef]

122. Dodds, J.A.; Bar-Joseph, M. Double-stranded RNA from plants infected with closteroviruses. Phytopathology 1983, 73, 419-423. [CrossRef]

123. Hajeri, S.; Killiny, N.; El-Mohtar, C.; Dawson, W.O.; Gowda, S. Citrus tristeza virus-based RNAi in citrus plants induces gene silencing in Diaphorina citri, a phloem-sap sucking insect vector of citrus greening disease (Huanglongbing). J. Biotechnol. 2014, 176, 42-49. [CrossRef]

124. Hada Wuriyanghan, C.R.; Falk, B.W. Oral delivery of double-stranded RNAs and siRNAs induces RNAi effects in the potato/tomato psyllid, Bactericerca cockerelli. PLOS ONE 2011, 6, e27736. [CrossRef]

125. Galdeano, D.M.; Breton, M.C.; Lopes, J.R.S.; Falk, B.W.; Machado, M.A. Oral delivery of double-stranded RNAs induces mortality in nymphs and adults of the Asian citrus psyllid, Diaphorina citri. PLoS ONE 2017, 12, e0171847. [CrossRef] [PubMed]

126. Kolora, L.D.; Powell, C.M.; Hunter, W.; Bextine, B.; Lauzon, C.R. Internal Extracellular Bacteria of Diaphorina citri Kuwayama (Hemiptera: Psyllidae), the Asian Citrus Psyllid. Curr. Microbiol. 2015, 70, 710-715. [CrossRef] [PubMed]

127. Gonella, E.; Tedeschi, R.; Crotti, E.; Alma, A. Multiple guests in a single host: Interactions across symbiotic and phytopathogenic bacteria in phloem-feeding vectors-A review. Entomol. Exp. Appl. 2019, 167, 171-185. [CrossRef]

128. Hawkings, C.; Morgan, K.; Shaffer, L.; Powell, C.; Borovsky, D.; Cave, R.; Dawson, B.; Gowda, S.; Shatters, R.G., Jr. RNAi-Based strategy for Asian Citrus Psyllid (Diaphorina citri) control: A method to reduce the spread of citrus greening disease. J. Citrus Pathol. 2014, 1, 160.

129. Christiaens, O.; Whyard, S.; Vélez, A.M.; Smagghe, G. Double-stranded RNA technology to control insect pests: Current status and challenges. Front. Plant Sci. 2020, 11, 451. [CrossRef]

130. Ghosh, S.; Sela, N.; Ghanim, M. Complete Genome Sequence of a Putative Densovirus Infecting the Carrot Psyllid Bactericera trigonica. Microbiol. Resour. Announc. 2019, 8, e01103-19. [CrossRef]

131. Nigg, J.C.; Falk, B.W. Diaphorina citri densovirus is a persistently infecting virus with a hybrid genome organization and unique transcription strategy. J. Gen. Virol. 2020, 101, 226-239. [CrossRef] 
132. Britt, K.; Gebben, S.; Levy, A.; Al Rwahnih, M.; Batuman, O. The Detection and Surveillance of Asian Citrus Psyllid (Diaphorina citri)—Associated Viruses in Florida Citrus Groves. Front. Plant Sci. 2020, 10, 1687. [CrossRef]

133. Whitten, M.M.A.; Facey, P.D.; Del Sol, R.; Fernández-Martínez, L.T.; Evans, M.C.; Mitchell, J.J.; Bodger, O.G.; Dyson, P.J. Symbiont-mediated RNA interference in insects. Proc. R. Soc. B Biol. Sci. 2016, 283, 20160042. [CrossRef]

134. Goodfellow, S.; Zhang, D.; Wang, M.-B.; Zhang, R. Bacterium-Mediated RNA Interference: Potential Application in Plant Protection. Plants 2019, 8, 572. [CrossRef]

135. Scott, J.G.; Michel, K.; Bartholomay, L.C.; Siegfried, B.D.; Hunter, W.B.; Smagghe, G.; Zhu, K.Y.; Douglas, A.E. Towards the elements of successful insect RNAi. J. Insect Physiol. 2013, 59, 1212-1221. [CrossRef] [PubMed]

136. Tian, H.; Peng, H.; Yao, Q.; Chen, H.; Xie, Q.; Tang, B.; Zhang, W. Developmental control of a lepidopteran pest Spodoptera exigua by ingestion of bacteria expressing dsRNA of a non-midgut gene. PLoS ONE 2009, 4, e6225. [CrossRef] [PubMed]

137. Hunter, W.B.; Gonzalez, M.T.; Tomich, J. BAPC-assisted CRISPR/Cas9 System: Targeted Delivery into Adult Ovaries for Heritable Germline Gene Editing (Arthropoda: Hemiptera). BioRxiv 2018, 1, 451559.

138. Zheng, Z.; Bao, M.; Wu, F.; Chen, J.; Deng, X. Predominance of single prophage carrying a CRISPR/cas system in "Candidatus Liberibacter asiaticus" strains in southern China. PLoS ONE 2016, 11, e0146422. [CrossRef]

(C) 2020 by the authors. Licensee MDPI, Basel, Switzerland. This article is an open access article distributed under the terms and conditions of the Creative Commons Attribution (CC BY) license (http://creativecommons.org/licenses/by/4.0/). 